\title{
EFFECT OF SALINITY AND HUMIC ACID TREATMENTS ON GROWTH AND CHEMICAL COMPOSITION OF CHORISIA SPECIOSA PLANTS
}

(Received: 7.10. 2014)

\author{
By \\ N. A. El-Shanhorey, N. H. Mohamed* and M. Z.M. Salem ** \\ Botanical Gardens Research Department, and "Timber Trees Research Department, Horticulture \\ Research Institute, Agriculture Research Center, Alexandria, Egypt. \\ ${ }^{* *}$ Forestry and Wood Technology Department, Faculty of Agriculture (EL-Shatby), Alexandria \\ University, Alexandria, Egypt.
}

\begin{abstract}
This investigation was carried out at Antoniades Research Branch, Horticulture Institute, Ministry of Agriculture, Alexandria, Egypt, during 2012 and 2013 seasons. The study was a trial to investigate the effect of different levels of salinity $(0,3000,6000$ and $9000 \mathrm{ppm})$ and different concentrations of humic acid sprayed on the leaves $(0,500,1000$ and $1500 \mathrm{ppm})$ and their combinations on the vegetative growth and some chemical constituents of Chorisia speciosa plants grown in plastic pots $30 \mathrm{~cm}$ filled with sandy soil. The results revealed that the salinity levels of irrigation were more effective than humic acid concentrations on all the studied characteristics of Chorisia speciosa plant. Additionally, using tap water (control) combined with humic acid at $1000 \mathrm{ppm}$ gave the highest significant values of plant height, stem dry weight, leaf number, leaf dry weight, leaf area. Additionally, using tap water (control) combined with humic acid at $1500 \mathrm{ppm}$ gave the highest significant values of stem diameter, root length, root dry weight, chlorophyll, proline and carbohydrates contents of the leaves. Generally, the obtained results recommend that irrigating the cultivated plants in the sandy soil three times per week with using irrigation salinity water level no more than $6000 \mathrm{ppm}$ combined with humic acid at the rate of $1500 \mathrm{ppm}$ improved the vegetative growth and some chemical constituents of Chorisia speciosa plants.
\end{abstract}

Key words: Chorisia speciosa, humic acid, salinity irrigation water.

\section{INTRODUCTION}

Chorisia speciosa, the Silk Floss tree or Kapok tree, is a decorative tree from the Bombacaceae family that originated in Brazil and Argentina (Santos, 1967 and Pio Correa, 1978). It grows up to 20 meters high and 20 meters wide. Its spectacular blooming attracts every eye. The plant blooms mostly in autumn. The large white, pink or red flowers are very attractive and measure up to $12 \mathrm{~cm}$ long. The foliage is semi-persistent and light green. The leaves fall off right before blooming, so the flowers cover the entire tree. The trunk is green and has large grey spikes covering it as it gets older. It is easy to cultivate, pruned before the next blooming season. This species has great economic and ornamental potentials, living preferentially in wet habitats, being frequent in river valleys and small depressions (Santos, 1967). Dias et al. (1992) classified this species as secondary in the ecological succession.

Salinity is one of major environmental factors determining plant productivity and plant distribution. Salinity affects more than $10 \%$ of Arab lands. In general, desertification and salinization are rapidly increasing on a global scale, leading to declining the average yields of most major crop plants. Several researchers reported that water salinity also has considerable effect on the growth of different ornamental tree species (Sapeta et al., 2013).

Humic substances have different effects on plants. Vaughan et al. (1985), showed evidence of stimulation of plant growth by humic substances and consequently increased yield by acting on mechanisms involved in cell 
respiration, photosynthesis, protein synthesis, water, and nutrient uptake, enzyme activities.

Results demonstrated that it is $\mathrm{C}$ rate dependent and particularly effective at low concentration (Chen and Aviad, 1990). Optimal concentrations capable to affect and stimulate plant growth have been generally found in the range of 50-300 $\mathrm{mg} \mathrm{l}^{-1}$, but positive effects have been also seen with lower concentrations (Chen et al., 2004). Cavalcante et al. (2011) demonstrated that sprayed humic substances positively affect aerial parts and root systems of papaya seedlings, and seedling quality are improved by humic acid foliar spray. Khaled and Fawy (2011) stated that "economical levels of application should be determined and should not exceed $2 \mathrm{~g}$ humus $/ \mathrm{kg}$ in soil and $0.1 \%$ in foliar".

Additionally, Chorisia speciosa are known to be relatively tolerant to salinity (Genhua et al., 2012). However, significant reduction in vegetative growth characteristics is expected to occur if the salinity level is increased above a certain critical level. This study was conducted with the aim of investigating the effect of different irrigation water salinity levels on the growth and chemical constituents of Chorisia speciosa, and to assess the possibility of using humic acid treatments to overcome the adverse effects of salinity on plant growth.

\section{MATERIALS AND METHODS}

The present study was carried-out at Antoniades Research Branch, Horticulture Research Institute, A.R.C. Alexandria, Egypt during the two successive seasons of 2012 and 2013.

On the $15^{\text {th }}$ of March, 2012 and 2013 (in the first and second seasons, respectively) homogenous seedlings of Chorisia speciosa (30$35 \mathrm{~cm}$ height and 7-9 compound leaf/ plant in average) were planted individually in plastic pots $(30 \mathrm{~cm}$ diameter) filled with $10 \mathrm{~kg}$ of sandy soil. The chemical constituents of the soil were measured as described by Jackson (1958) in Table (1). On the $15^{\text {th }}$ of April (in both seasons), the saline irrigation water treatments were initiated. The different saline water concentrations were prepared, using sodium chloride $(\mathrm{NaCl})$. The plants were irrigated three times per week using saline water concentrations of tap water (control), 3000, 6000 and 9000 ppm. In both seasons, the plants received the salinity levels monthly from 15 April till 15 August in both seasons. The plants also were sprayed with humic acid at the concentrations of 0, 500, 1000 and $1500 \mathrm{ppm}$, monthly from 15 May till 15 August in both seasons. Control plants were sprayed with tap water. The end of the experiment was on the $15^{\text {th }}$ of September (in both seasons).

In both seasons, all plants received NPK chemical fertilization using fertilizer (Milagro Aminoleaf 20-20-20) at the rate of $3 \mathrm{~g} /$ pot. Fertilization was repeated every 30 days throughout the growing season (from the $20^{\text {th }}$ of April till the $15^{\text {th }}$ of August). In addition, weeds were removed manually upon emergence.

Data recorded : (at the end of the season)

1. Vegetative growth parameters: Plant height $(\mathrm{cm})$, leaf number per plant, leaf area $\left(\mathrm{cm}^{2}\right)$, leaf dry weight per plant $(\mathrm{g})$, stem diameter $(\mathrm{cm})$, stem dry weight $(\mathrm{g})$, root length $(\mathrm{cm})$ and root dry weight (g).

\section{Chemical analysis determination}

- Chlorophylls content were determined as SPAD unites of the fresh leaves of plants for the different treatments under the experiment at the end of the season using Minolta (chlorophyll meter) SPAD 502 according to Yadava (1986).

- Carbohydrate contents of the leaves were determined according to Dubios et al.(1956).

- Sodium and chloride contents \% of dry matter in the leaves were determined according to Piper (1947).

- Relative Water Content of the leaves (\%) in the fresh leaves were determined according to Barrs (1968) and Ritche (1974).

- Proline content $(\mathrm{mg} / \mathrm{g})$ in the leaves was determined according to Bates et al. (1973).

The layout of the experimental design was split plot design with three replicates. Each replicate contained three plants. The main plots were the salinity levels while the sub plots were

Table (1): Some chemical analysis of the used sandy soil for the two successive seasons 2012 and 2013.

\begin{tabular}{|l|c|c|c|c|c|c|c|c|c|}
\hline Season & $\mathbf{p H}$ & \multirow{2}{*}{$\begin{array}{c}\mathbf{E C} \\
\left.\mathbf{d S m}^{-1}\right)\end{array}$} & \multicolumn{3}{|c|}{ Soluble cations (mg/l) } & \multicolumn{3}{c|}{ Soluble anions (mg/l) } \\
\cline { 4 - 10 } & & $\mathbf{C a}^{++}$ & $\mathbf{M g}^{++}$ & $\mathbf{N a}^{+}$ & $\mathbf{K}^{+}$ & $\mathbf{H C O}_{\mathbf{3}}^{-}$ & $\mathbf{C l}^{-}$ & $\mathbf{S O}_{2}^{--}$ \\
\hline $\mathbf{2 0 1 2}$ & 7.87 & 1.51 & 3.1 & 4.2 & 6.4 & 1.1 & 3.5 & 6.5 & 2.4 \\
\hline $\mathbf{2 0 1 3}$ & 7.92 & 1.43 & 3.4 & 2.9 & 6.2 & 0.9 & 3.2 & 6.3 & 2.1 \\
\hline
\end{tabular}


the concentrations of humic acid. The means of the individual factors and their interactions were compared by L.S.D test at 5\% level of probability according to Snedecor and Cochran (1974).

\section{RESULTS AND DISCUSSION \\ 3.1. Vegetative growth \\ 3.1.1. Plant height $(\mathrm{cm})$}

Data presented in Table (2a) show that, in both seasons, irrigation with saline water decreased the height of Chorisia speciosa plants, compared to the plants irrigated with tap water (control). Plants irrigated with tap water had the highest mean values of plant height 41.12 and $43.54 \mathrm{~cm}$ in the first and second seasons, respectively. Moreover, raising the salt concentration caused steady significant reductions in plant height, with the highest concentration $(9000 \mathrm{ppm})$ giving significantly the shortest plants (with mean heights of 29.62 and $32.45 \mathrm{~cm}$ in the two seasons, respectively) than those receiving any other salt concentration. Similar results were reported by Abd El-Aziz et al. (2006) on Khaya senegalensis, El- Juhany et al. (2008) on Eucalyptus camaldulensis, Eucalyptus intertexta and Eucalyptus microtheca, and Sharif and Khan (2009) on Salvadora oleoides, Prosopis cineraria, Capparis decidue and Tamarix aphylla. The reduction in plant height as a result of high salt concentration was explained by Yasseen et al. (1987) and St.Arnaud and Vincent (1990), as the decrease in plant height under saline conditions was probably due to the insufficient uptake of water and nutrients, as well as sodic toxicity.

Plant height was also significantly affected by spraying the plants with humic acid. In both seasons, plant height was increased gradually when the humic acid concentration was raised from $0 \mathrm{ppm}$ (control) to $1000 \mathrm{ppm}$. However, a further increase in humic acid concentration from $1000 \mathrm{ppm}$ to $1500 \mathrm{ppm}$ resulted in a gradual decrease in plant height. Accordingly, it can be seen from the data in Table (2-a) that Chorisia speciosa plants sprayed with $1000 \mathrm{ppm}$ humic acid were significantly taller (with mean plant heights of 37.41 and $40.04 \mathrm{~cm}$ in the first and second seasons, respectively) than the plants sprayed with any other humic acid concentration. The increase in height of Chorisia speciosa plants as a result of spraying with humic acid is similar to the increases in height that had been recorded on other ornamental plant species, by El-Khateeb et al. (2010) on Calia secundiflora and Cavalcante et al. (2011) on Carica papaya.

Regarding the interaction between the effects of irrigation water salinity and humic acid treatments on growth rate of the plant height of Chorisia speciosa plants, the results recorded in the two seasons show that, the highest values were obtained in the plants irrigated with tap water and sprayed with humic acid at $1000 \mathrm{ppm}$ (with mean heights of 43.50 and $45.83 \mathrm{~cm}$ in the first and second seasons, respectively). On the other hand, the shortest plants (with mean heights of 26.25 and $28.50 \mathrm{~cm}$ in the first and second seasons, respectively) were the plants irrigated using the highest salt concentration 9000 ppm without humic acid treatment. It can also be seen from the data presented in Table (2a) that in many cases, spraying the plants with humic acid reduced the undesirable effect of salinity. Similar results were reported by Abd El-Aziz et al. (2006) on Khaya senegalensis, Sayed (2006) on Ficus alii, El-Juhany et al. (2008) on Eucalyptus camaldulensis, Eucalyptus intertexta and Eucalyptus microtheca and Sharif and Khan (2009) on Salvadora oleoides, Prosopis cineria, Capparis decidue and Tamarix aphylla.

\subsubsection{Number of leaves per plant}

The data presented in Table (2a) show the effect of saline water on the number of leaves formed on Chorisia speciosa plants. In both seasons, plants irrigated with tap water had the highest number of leaves 30.08 and 32.41 leaves/plant in the first and second seasons, respectively. Accordingly, the least number of leaves 22.33and 24.95 leaves/plant in the first and second seasons, respectively, was formed by plants that were irrigated using the highest salt concentration $9000 \mathrm{ppm}$. Similar results were reported by El-Juhany and Aref (2005) on Conocarpus erectus, Abd EI-Aziz et al. (2006) on Khaya senegalensis and El-Juhany et al. (2008) on Eucalyptus camaldulensis, Eucalyptus intertexta and Eucalyptus microtheca.

Concerning the effect of humic acid treatments on the number of leaves, the data recorded in the two seasons in Table (2a) show that humic acid treatment at $1000 \mathrm{ppm}$ caused a significant increase in the number of leaves giving mean values of 27.62 and 29.91 leaves/plant in the first and second seasons, respectively, compared to that of the control plants (23.79 and 26.04 leaves/plant in the two 
seasons, respectively). The increase in the number of leaves of plants sprayed with humic acid at $1000 \mathrm{ppm}$ supports the results reported by Fathy et al. (2010) on Prunus armeniaca and El-Khateeb et al. (2010) on Calia secundiflora.

The data in Table (2a) show that significant interaction was detected in both seasons between the effects of irrigation water salinity and humic acid treatments on the number of leaves formed by Chorisia speciosa plants. Combining irrigation using tap water with spraying the plants with humic acid at $1000 \mathrm{ppm}$ gave the highest number of leaves of 31.66 and 33.66 leaves per plant in the first and second seasons, respectively. On the other hand, the least number of leaves per plant of 20.16 and 22.33 leaves per plant in the first and second seasons, respectively, were obtained on plants irrigated using the highest salt concentration 9000 ppm and sprayed without any humic acid concentration. Similar results were reported by
El-Juhany and Aref (2005) on Conocarpus erectus, Abd El-Aziz et al. (2006) on Khaya senegalensis, Sayed (2006) on Ficus alii and ElJuhany et al. (2008) on Eucalyptus camaldulensis, Eucalyptus intertexta and Eucalyptus microtheca.

\subsubsection{Leaves dry weight (g) per plant}

The results recorded in the two seasons (Table 2a) show that the heaviest dry weights of leaves were 26.89 and $30.11 \mathrm{~g} /$ plant in the first and second seasons, respectively, were obtained from plants irrigated with tap water. Irrigation with water containing any salt concentration decreased the dry weight of leaves significantly. Moreover, the recorded values decreased steadily with raising the salt concentration. Accordingly, the least values ( 17.91 and 21.17 $\mathrm{g} / \mathrm{plant}$ ) in the first and second seasons, respectively, were obtained from plants irrigated with the highest salt concentration $9000 \mathrm{ppm}$. This reduction in the dry weight of leaves as a

Table (2a): Means of vegetative growth characteristics of Chorisia speciosa plants as influenced by Salinity (S), Humic acid (HA) and their combinations $(\mathrm{S} \times \mathrm{HA})$ in the two seasons of 2012 and 2013.

\begin{tabular}{|c|c|c|c|c|c|c|c|}
\hline \multicolumn{2}{|c|}{ Treatments } & \multicolumn{2}{|c|}{ Plant height (cm) } & \multicolumn{2}{|c|}{$\begin{array}{c}\text { Number of leaf } \\
\text { per plant }\end{array}$} & \multicolumn{2}{|c|}{$\begin{array}{l}\text { Leaf dry weight (g) } \\
\text { per plant }\end{array}$} \\
\hline Salinity (ppm) & Humic acid (ppm) & 2012 & 2013 & 2012 & 2013 & 2012 & 2013 \\
\hline \multirow[t]{4}{*}{0} & 0 & 37.50 & 39.91 & 27.66 & 30.16 & 24.05 & 27.42 \\
\hline & 500 & 42.00 & 44.41 & 30.66 & 33.16 & 27.58 & 31.02 \\
\hline & 1000 & 43.50 & 45.83 & 31.66 & 33.66 & 28.74 & 31.61 \\
\hline & 1500 & 41.50 & 44.00 & 30.33 & 32.66 & 27.20 & 30.42 \\
\hline Mean & & 41.12 & 43.54 & 30.08 & 32.41 & 26.89 & 30.11 \\
\hline \multirow[t]{4}{*}{3000} & 0 & 33.25 & 35.25 & 24.83 & 26.83 & 20.72 & 23.41 \\
\hline & 500 & 36.50 & 38.50 & 27.00 & 29.00 & 23.27 & 26.02 \\
\hline & 1000 & 38.91 & 41.58 & 28.66 & 31.00 & 25.25 & 28.41 \\
\hline & 1500 & 35.75 & 38.25 & 27.16 & 28.83 & 22.69 & 25.81 \\
\hline Mean & & 36.10 & 38.39 & 26.91 & 28.91 & 22.98 & 25.91 \\
\hline \multirow[t]{4}{*}{6000} & 0 & 29.75 & 32.41 & 22.50 & 24.83 & 18.00 & 21.02 \\
\hline & 500 & 33.50 & 36.00 & 25.00 & 27.33 & 20.93 & 24.02 \\
\hline & 1000 & 35.25 & 37.91 & 26.16 & 28.50 & 22.31 & 25.42 \\
\hline & 1500 & 33.50 & 36.33 & 24.83 & 27.50 & 20.96 & 24.22 \\
\hline Mean & & 33.00 & 35.66 & 24.62 & 27.04 & 20.55 & 23.67 \\
\hline \multirow{4}{*}{9000} & 0 & 26.25 & 28.50 & 20.16 & 22.33 & 15.25 & 18.01 \\
\hline & 500 & 29.50 & 32.75 & 22.33 & 25.16 & 17.84 & 21.42 \\
\hline & 1000 & 32.00 & 34.83 & 24.00 & 26.50 & 19.76 & 23.02 \\
\hline & 1500 & 30.75 & 33.75 & 22.83 & 25.83 & 18.79 & 22.22 \\
\hline Mean & & 29.62 & 32.45 & 22.33 & 24.95 & 17.91 & 21.17 \\
\hline \multirow[t]{4}{*}{ Mean (HA) } & 0 & 31.68 & 34.02 & 23.79 & 26.04 & 19.50 & 22.46 \\
\hline & 500 & 35.37 & 37.91 & 26.25 & 28.66 & 22.41 & 25.62 \\
\hline & 1000 & 37.41 & 40.04 & 27.62 & 29.91 & 24.01 & 27.12 \\
\hline & 1500 & 35.37 & 38.08 & 26.29 & 28.70 & 22.41 & 25.67 \\
\hline \multirow[t]{3}{*}{ L.S.D. at 0.05} & $\mathbf{S}$ & 1.94 & 1.41 & 1.12 & $\begin{array}{l}0.88 \\
\end{array}$ & 1.41 & 1.02 \\
\hline & HA A & 0.70 & 0.58 & 0.55 & 0.36 & 0.56 & 0.43 \\
\hline & $\mathbf{H A} \times \mathbf{S}$ & 2.28 & 1.73 & 1.47 & 1.07 & 1.70 & 1.26 \\
\hline
\end{tabular}


result of salinity treatments is similar to that obtained by El-Juhany and Aref (2005) on Conocarpus erectus, and Abd El-Aziz et al. (2006) on Khaya senegalensis.

The data presented in Table (2a) also show that spraying Chorisia speciosa plants with humic acid at $1000 \mathrm{ppm}$ significantly increased the dry weight of leaves giving values of 24.01 and $27.12 \mathrm{~g} / \mathrm{plant}$ in the first and second seasons, respectively, compared to the control (19.50 and $22.46 \mathrm{~g} /$ plant in the first and second seasons, respectively).

Regarding the interaction between the effect of irrigation water salinity and humic acid treatments on the dry weight of leaves of Chorisia speciosa, the data presented in Table (2a) showed that the heaviest dry weights of leaves of $28.74 \mathrm{~g}$ and $31.61 \mathrm{~g} / \mathrm{plant}$ in the first and second seasons, respectively, were obtained in plants irrigated with tap water and sprayed with humic acid at $1000 \mathrm{ppm}$, whereas the least dry weights of leaves of 15.25 and $18.01 \mathrm{~g} /$ plant in the first and second seasons, respectively, were obtained when the plants were irrigated using the highest salt concentration $9000 \mathrm{ppm}$ without any humic acid treatment.

This reduction in the dry weight of leaves as a result of salinity treatments is similar to that obtained by El-Juhany and Aref (2005) on Conocarpus erectus, Abd El-Aziz et al. (2006) on Khaya senegalensis and Sayed (2006) on Ficus alii.

\subsubsection{Leaves area $\left(\mathrm{cm}^{2}\right)$}

The results recorded in the two seasons (Table 2b) show that irrigation with saline water decreased the leaf area of Chorisia speciosa plants, compared to the plants irrigated with tap water (control). In both seasons, plants irrigated with tap water (control) had the largest leaves with mean areas of 1874.11 and $2016.39 \mathrm{~cm}^{2}$ in the first and second seasons, respectively. The leaves area was decreased steadily with raising the salt concentration. Accordingly, the smallest leaf with mean areas of 475.09 and $515.44 \mathrm{~cm}^{2}$ in the first and second seasons, respectively, formed on plants that were irrigated using the highest salt concentration $9000 \mathrm{ppm}$. Similar results were reported by Awan et al. (2002a) on Eucalyptus camaldulensis, and Awan et al. (2002b) on Dalbergia sissoo.

The data presented in Table (2b) show that, the different humic acid treatments had a significant effect on leaves area of Chorisia speciosa plants. Plants sprayed using humic acid at $1000 \mathrm{ppm}$ forming significantly larger leaves (with a mean area of 1301.65 and $1384.84 \mathrm{~cm}^{2}$ in the first and second seasons, respectively, than those formed by the control plants (806.79 and $878.48 \mathrm{~cm}^{2}$ ). Similar increases in leaf area as a result of humic acid treatments were reported by Fathy et al. (2010) on Prunus armeniaca.

The data presented in Table (2b) also show that a significant interaction was detected between the effect of irrigation water salinity and humic acid treatments on the area of Chorisia speciosa leaves. The largest leaves with mean areas of 2062.12 and $2206.89 \mathrm{~cm}^{2}$ in the first and second seasons, respectively, were obtained by plants irrigated with tap water and sprayed with humic acid at 1000 or $1500 \mathrm{ppm}$, respectively. On the other hand, the smallest leaves (with areas of 403.57 and $452.57 \mathrm{~cm}^{2}$ in the first and second seasons, respectively) were obtained on plants irrigated using the highest salt concentration 9000 ppm combined with control (without humic acid treatment). Similar results were reported by Awan et al. (2002a) on Eucalyptus camaldulensis, and Awan et al. (2002b) on Dalbergia sissoo.

It can also be seen that in many cases, the humic acid treatments counteracted (at least partly) the adverse effect of the salinity treatments on leaf area. For example, in the plants that were irrigated using the highest salt concentration $9000 \mathrm{ppm}$, a steady increase in leaf area was recorded as the humic acid concentration was gradually raised, i.e. in both seasons, plants that were irrigated with saline water at $9000 \mathrm{ppm}$ and sprayed with humic acid gave larger leaves than plants receiving the same salinity treatment, but without humic acid.

\subsubsection{Stem diameter $(\mathbf{c m})$}

The data recorded on the stem diameter of Chorisia speciosa plants in the two seasons (Table 2b) show that irrigation with saline water decreased stem thickness, compared to that of plants irrigated with tap water (control). In both seasons, plants irrigated with tap water had the thickest stems, with mean diameters of 3.66 and $4.09 \mathrm{~cm}$ in the first and second seasons, respectively. Raising the salt concentration in irrigation water caused a steady reduction in stem diameter. This reduction in stem diameter was significant (compared to the control), even at the highest salt concentration $9000 \mathrm{ppm}$, which gave stem diameters of 2.63 and $3.00 \mathrm{~cm}$ in the first and second seasons, respectively. Similar results were reported by Abd El-Aziz et 
al. (2006) on Khaya senegalensis.

In contrast to the effect of salinity treatments, humic acid treatments improved stem diameter of Chorisia speciosa plants, compared to the control. Moreover, plants sprayed with 1500 ppm humic acid significantly affected thickest stems (with mean diameters of 3.42 and $3.69 \mathrm{~cm}$ in the first and second seasons, respectively), compared to the those of control plants, or plants sprayed with any other humic acid concentration. Similar increases in stem diameter had been reported by El-Khateeb et al. (2010) on Calia secundiflora and Fathy et al. (2010) on Prunus armeniaca.

Regarding the interaction between the effects of irrigation water salinity and humic acid treatments on stem diameter of Chorisia speciosa plants, the results recorded in the two seasons in Table (2b) show that significant differences were detected between the values obtained from plants receiving the different treatment combinations. The highest values (3.83 and $4.29 \mathrm{~cm}$ in the first and second seasons, respectively) were obtained in the plants irrigated with tap water and sprayed with humic acid at $1500 \mathrm{ppm}$. On the other hand, the thinnest stems (with diameters of 2.24 and 2.57 $\mathrm{cm}$ in the first and second seasons, respectively) were obtained in the plants irrigated using the highest salt concentration $9000 \mathrm{ppm}$ without humic acid treatment. It can also be seen that in some cases, the humic acid treatments helped to overcome the adverse effect of the salinity treatments on stem thickening. Similar results were reported by El-Bagoury et al. (1999) on Casuarina equisetifolia and Abd El-Aziz et al. (2006) on Khaya senegalensis.

\subsubsection{Stem dry weight $(\mathrm{g})$}

Data presented in Table (2b) show that, in both seasons, irrigation with saline water significantly decreased dry weights of the stems of Chorisia speciosa plants, compared to plants

Table (2b): Means of vegetative growth characteristics of Chorisia speciosa plants as influenced by Salinity (S), Humic acid (HA) and their combinations $(S \times H A)$ in the two seasons of 2012 and 2013.

\begin{tabular}{|c|c|c|c|c|c|c|c|}
\hline \multicolumn{2}{|r|}{ Treatments } & \multicolumn{2}{|c|}{ Leaf area $\left(\mathrm{cm}^{2}\right)$} & \multicolumn{2}{|c|}{ Stem diameter $(\mathrm{cm})$} & \multicolumn{2}{|c|}{ Stem dry weight (g) } \\
\hline Salinity (ppm) & Humic acid (ppm) & 2012 & 2013 & 2012 & 2013 & 2012 & 2013 \\
\hline \multirow[t]{4}{*}{0} & 0 & 1693.90 & 1823.44 & 3.39 & 3.77 & 31.46 & 34.98 \\
\hline & 500 & 1721.90 & 1861.80 & 3.68 & 4.07 & 34.12 & 38.45 \\
\hline & 1000 & 2062.12 & 2173.42 & 3.75 & 4.23 & 36.21 & 38.91 \\
\hline & 1500 & 2018.51 & 2206.89 & 3.83 & 4.29 & 34.61 & 38.72 \\
\hline Mean & & 1874.11 & 2016.39 & 3.66 & 4.09 & 34.10 & 37.76 \\
\hline \multirow[t]{4}{*}{3000} & 0 & 660.56 & 715.17 & 2.94 & 3.18 & 27.52 & 30.22 \\
\hline & 500 & 1073.22 & 1152.28 & 3.23 & 3.41 & 30.13 & 32.27 \\
\hline & 1000 & 1367.23 & 1478.09 & 3.48 & 3.56 & 32.65 & 33.75 \\
\hline & 1500 & 709.54 & 773.49 & 3.63 & 3.65 & 31.49 & 33.91 \\
\hline Mean & & 952.64 & 1029.76 & 3.32 & 3.45 & 30.44 & 32.54 \\
\hline \multirow[t]{4}{*}{6000} & 0 & 469.13 & 522.75 & 2.59 & 2.94 & 24.45 & 27.51 \\
\hline & 500 & 812.01 & 892.06 & 2.93 & 3.28 & 27.51 & 30.51 \\
\hline & 1000 & 1028.36 & 1123.75 & 3.13 & 3.43 & 29.40 & 31.82 \\
\hline & 1500 & 535.03 & 592.40 & 3.30 & 3.52 & 28.15 & 31.92 \\
\hline Mean & & 711.13 & 782.74 & 2.99 & 3.29 & 27.38 & 30.44 \\
\hline \multirow[t]{4}{*}{9000} & 0 & 403.57 & 452.57 & 2.24 & 2.57 & 21.19 & 24.16 \\
\hline & 500 & 365.91 & 418.15 & 2.57 & 2.97 & 24.34 & 27.56 \\
\hline & 1000 & 748.91 & 764.12 & 2.78 & 3.19 & 26.33 & 29.30 \\
\hline & 1500 & 381.97 & 426.92 & 2.94 & 3.28 & 26.38 & 29.88 \\
\hline Mean & & 475.09 & 515.44 & 2.63 & 3.00 & 24.56 & 27.72 \\
\hline \multirow[t]{4}{*}{ Mean (HA) } & 0 & 806.79 & 878.48 & 2.79 & 3.11 & 26.15 & 29.22 \\
\hline & 500 & 993.26 & 1081.07 & 3.10 & 3.43 & 29.03 & 32.20 \\
\hline & 1000 & 1301.65 & 1384.84 & 3.28 & 3.60 & 31.15 & 33.44 \\
\hline & 1500 & 911.26 & 999.92 & 3.42 & 3.69 & 30.16 & 33.61 \\
\hline \multirow[t]{3}{*}{ L.S.D. at 0.05} & $\mathbf{S}$ & 76.16 & 46.34 & 0.22 & 0.16 & 0.93 & 1.72 \\
\hline & H A & 17.44 & 14.93 & 0.10 & 0.05 & 0.73 & 0.52 \\
\hline & $\mathbf{H A} \times \mathbf{S}$ & 81.75 & 52.88 & 0.26 & 0.17 & 1.56 & 1.93 \\
\hline
\end{tabular}


irrigated with tap water (control). Plants irrigated with tap water had the heaviest mean dry weight of stems 34.10 and $37.76 \mathrm{~g}$ per plant in the first and second seasons, respectively. The dry weight of the stems showed a gradual reduction as the salt concentration was increased. Accordingly, the least dry weights of stem 24.56 and $27.72 \mathrm{~g}$ per plant in the first and second seasons, respectively, were recorded in plants receiving the highest salt concentration 9000 $\mathrm{ppm}$. These results are in agreement with the fmdings of Aslam et al.(2002) on Eucalyptus camaldulensis, Franklin et al. (2002) on jack pine (Pinus banksiana), Gupta et al. (2002) on Ziziphus rotundifolia and Z. nummularia, ElFeky (2004) on Erythrina indica and Tecoma stans, and Abd El-Aziz et al. (2006) on Khaya senegalensis.

The results recorded in the two seasons in Table (2b) show that, spraying the plants with humic acid increased the dry weight of the stems. In both seasons, spraying plants with $1000 \mathrm{ppm}$ humic acid gave the heaviest dry weight of stem ( 31.15 and $33.44 \mathrm{~g} /$ plant) in the first and second seasons, respectively. These values were significantly higher than those of the control plants, or the plants receiving any other humic acid concentration. Increases in the dry weight of the stems as a result of humic acid treatments were reported by Hussein (2009) on Cryptostegia grandiflora.

Regarding the interaction between the effect of irrigation water salinity and humic acid treatments, the results recorded in the two seasons show that the heaviest stem dry weights of 36.21 and $38.91 \mathrm{~g}$ per plant in the first and second seasons, respectively) were those of plants irrigated with tap water and sprayed with humic acid at $1000 \mathrm{ppm}$. On the other hand, the lowest stem dry weights (21.19 and 24.16 g per plant in the first and second seasons, respectively) were obtained in the plants irrigated using the highest salt concentrations 9000 ppm without humic acid treatment. These results are in agreement with the findings of Aslam et al. (2002) on Eucalyptus camaldulensis, Franklin et al. (2002) on Pinus banksiana, Gupta et al. (2002) on Ziziphus rotundifolia and Ziziphus nummularia, ElFeky (2004) on Erythrina indica and Tecoma stans, and Abd El-Aziz et al. (2006) on Khaya senegalensis.

\subsubsection{Root length $(\mathrm{cm})$}

Data presented in Table (2c) show that all the tested irrigation water salinity treatments significantly decreased the root length $(\mathrm{cm})$ of Chorisia speciosa, compared to that of plants irrigated with tap water (control). In both seasons, plants irrigated with tap water had the highest mean root length 42.25 and $45.45 \mathrm{~cm}$ in the first and second seasons, respectively. Raising the salt concentration caused a steady reduction in the root length, which reached its lowest values of 31.00 and $34.97 \mathrm{~cm}$ in the first and second seasons, respectively, in the plants irrigated using the highest salt concentration at $9000 \mathrm{ppm}$. Similar results were reported by ElFeky (2004) on Erythrina indica and Tecoma stans and Abd El-Aziz et al. (2006) on Khaya senegalensis.

The data in Table (2c) also indicate that humic acid treatments had a significant effect on the root length. As with the other vegetative growth parameters, spraying the plants with humic acid at $1500 \mathrm{ppm}$ gave the tallest root length 38.52 and $43.06 \mathrm{~cm}$ in the first and second seasons, respectively. A similar increase in the root length as a result of humic acid treatments was recorded by Ashish et al. (2010) on Jatropha curcas.

Regarding the interaction between the effects of irrigation water salinity and humic acid treatments on root length of Chorisia speciosa plants, the results recorded in the two seasons, showed that, the highest values were obtained in plants irrigated with tap water and sprayed with humic acid at $1500 \mathrm{ppm}$ (with mean length of 44.33 and $47.75 \mathrm{~cm}$ in the first and second seasons, respectively). On the other hand, the shortest roots (with mean length of 26.91 and $30.66 \mathrm{~cm}$ in the first and second seasons, respectively) were those irrigated using the highest salt concentration at $9000 \mathrm{ppm}$ without humic acid treatment. It can also be seen from the data presented in Table (2c) that in many cases, spraying the plants with humic acid reduced the undesirable effect of salinity.

\subsubsection{Root dry weight (g)}

Data presented in Table (2c) show that irrigation of Chorisia speciosa plants with saline water significantly decreased the dry weights of roots, compared to the plants irrigated with tap water (control). In both seasons, plants irrigated with tap water had the highest dry weights of roots 37.00 and $42.38 \mathrm{~g} /$ plant in the first and second seasons, respectively. Steady significant reductions in the dry weight of roots were recorded as the salt concentration in the irrigation water was increased, with the highest salt concentration at $9000 \mathrm{ppm}$ 
giving the lowest mean values in both seasons 26.62 and $31.56 \mathrm{~g} / \mathrm{plant}$ in the first and second seasons, respectively.

Regarding the effect of humic acid treatments on the dry weight of roots, data in Table (2c) show that spraying Chorisia speciosa plants with humic acid at $1500 \mathrm{ppm}$ significantly increased the recorded values, compared to the control. The highest dry roots 33.63 and $39.05 \mathrm{~g} / \mathrm{plant}$ in respectively) were obtained in the plants irrigated with tap water and sprayed with humic acid at $1500 \mathrm{ppm}$. On the other hand, the least dry weight of roots (22.58 and $27.01 \mathrm{~g}$ per plant in the first and second seasons, respectively) were obtained from plants irrigated using the highest salt concentration 9000 ppm, with no humic acid treatment. Similar results were reported by Sayed (2006) on Ficus alii.

Table (2c): Means of vegetative growth characteristics of Chorisia speciosa plants as influenced by Salinity (S), Humic acid (HA) and their combinations (S× HA) in the two seasons of 2012 and 2013.

\begin{tabular}{|c|c|c|c|c|c|}
\hline \multicolumn{2}{|c|}{ Treatments } & \multicolumn{2}{|c|}{ Root length (cm) } & \multicolumn{2}{|c|}{ Root dry weight (g) } \\
\hline Salinity (ppm) & Humic acid (ppm) & 2012 & 2013 & 2012 & 2013 \\
\hline \multirow{4}{*}{0} & 0 & 38.33 & 42.25 & 33.55 & 38.92 \\
\hline & 500 & 42.66 & 45.08 & 37.71 & 42.33 \\
\hline & 1000 & 43.66 & 46.75 & 38.27 & 43.94 \\
\hline & 1500 & 44.33 & 47.75 & 38.50 & 44.34 \\
\hline \multicolumn{2}{|l|}{ Mean } & 42.25 & 45.45 & 37.00 & 42.38 \\
\hline \multirow{4}{*}{3000} & 0 & 34.00 & 37.41 & 29.27 & 34.21 \\
\hline & 500 & 36.66 & 40.83 & 32.57 & 36.50 \\
\hline & 1000 & 38.00 & 43.08 & 34.75 & 38.59 \\
\hline & 1500 & 39.50 & 44.91 & 34.55 & 39.91 \\
\hline \multicolumn{2}{|l|}{ Mean } & 37.04 & 41.56 & 32.78 & 37.30 \\
\hline \multirow{4}{*}{6000} & 0 & 30.58 & 34.41 & 26.14 & 31.41 \\
\hline & 500 & 34.33 & 37.75 & 29.56 & 34.38 \\
\hline & 1000 & 35.91 & 39.50 & 31.20 & 36.17 \\
\hline & 1500 & 36.50 & 41.25 & 32.11 & 37.07 \\
\hline \multicolumn{2}{|l|}{ Mean } & 34.33 & 38.22 & 29.75 & 34.75 \\
\hline \multirow{4}{*}{9000} & 0 & 26.91 & 30.66 & 22.58 & 27.01 \\
\hline & 500 & 30.50 & 34.25 & 26.07 & 30.78 \\
\hline & 1000 & 32.83 & 36.66 & 28.45 & 33.58 \\
\hline & 1500 & 33.75 & 38.33 & 29.37 & 34.89 \\
\hline \multicolumn{2}{|l|}{ Mean } & 31.00 & 34.97 & 26.62 & 31.56 \\
\hline \multirow{4}{*}{ Mean (HA) } & 0 & 32.45 & 36.18 & 27.88 & 32.88 \\
\hline & 500 & 36.04 & 39.47 & 31.48 & 35.99 \\
\hline & 1000 & 37.60 & 41.50 & 33.16 & 38.07 \\
\hline & 1500 & 38.52 & 43.06 & 33.63 & 39.05 \\
\hline \multirow{3}{*}{ L.S.D. at 0.05} & $\mathbf{S}$ & 1.60 & 1.14 & 1.70 & 1.61 \\
\hline & H A & 0.85 & 0.42 & 0.93 & 0.46 \\
\hline & $\mathbf{S} \times \mathbf{H A}$ & 2.17 & 1.34 & 2.34 & 1.79 \\
\hline
\end{tabular}

the first and second seasons, respectively, were those of plants sprayed with humic acid at 1500 ppm. A similar increase in the dry weight of roots was recorded by Zaghloul et al. (2009) on Thuja orientalis, El-Khateeb et al. (2010) on Calia secundiflora and Cavalcante et al. (2011) on Carica papaya.

Regarding the interaction between the effects of irrigation water salinity and humic acid treatments, the data presented in Table (2c) show that the highest values (38.50 and $44.34 \mathrm{~g}$ per plant in the first and second seasons,

\subsection{Chemical constituents}

\subsubsection{Chlorophyll content (SPAD unites)}

The results presented in Table (3a) show that the highest content of total chlorophylls was obtained in the plants irrigated with tap water 44.52 and 50.04 SPAD in the first and second seasons, respectively. Raising the salt concentration in irrigation water resulted in steady significant reductions in the total chlorophyll content, which reached its lowest values of 39.98 and 45.41 SPAD in the first and second seasons, respectively, in plants receiving 
the highest salt concentration $9000 \mathrm{ppm}$. The decrease in the total chlorophyll content as a result of raising the salt concentration in irrigation water are in agreement with the results reported by El-Feky (2004) on Erythrina indica and Tecoma stans, and Helmy (2004) on Senna occidentalis.

The results of leaf chemical analysis in Table (3a) also show that the tested humic acid treatments had clear effect on the total chlorophyll content. The recorded mean values ranged from 44.91 and 49.93 SPAD in the first and second seasons, respectively, in plants sprayed with humic acid at $1500 \mathrm{ppm}$ to 38.42 and 44.18 SPAD in the first and second seasons, respectively, in the plants sprayed with humic acid at $0 \mathrm{ppm}$. Similar results were reported by Tejada and Gonzalez (2003) on asparagus, and Ferrara et al. (2008) on grape.

The data presented in Table (3a) also show that significant interaction was detected between the effect of irrigation water salinity and humic acid treatments of Chorisia speciosa leaves. In the first season, the highest total chlorophylls content of 45.99 SPAD was formed by plants irrigated with tap water and sprayed with humic acid at $1000 \mathrm{ppm}$. In the second season, the highest chlorophyll mean 51.75 SPAD was formed by the plants irrigated with tap water and sprayed with humic acid at $1500 \mathrm{ppm}$. On the other hand, the least chlorophyll contents 35.44 and 41.54 SPAD in the first and second seasons, respectively) were obtained in the plants irrigated using the highest salt concentration at $9000 \mathrm{ppm}$ combined with humic acid at $0 \mathrm{ppm}$ treatment. The decrease in the total chlorophyll content as a result of raising the salt concentration in irrigation water is in agreement with the results reported by El-Feky (2004) on Erythrina indica and Tecoma stans, and Helmy (2004) on Senna occidentalis.

\subsubsection{Carbohydrate content (\%)}

The data resulting from leaf chemical analysis in Table (3a) show that, the total carbohydrates \% in the dried leaves of Chorisia speciosa plants was decreased steadily with raising the salt concentration in the irrigation water. The highest mean of carbohydrate content 17.51 and $18.03 \%$ in the first and second seasons, respectively, were found in the leaves of the control plants, whereas the least mean values 15.68 and $16.31 \%$ in the first and second seasons, respectively, were found in the plants irrigated with water containing the highest salt concentration at $9000 \mathrm{ppm}$. Decreases in the carbohydrate \% with increasing the salinity level have been reported by El-Feky (2004) on Erytherina indica and Tecoma stans. The reduction in the carbohydrate content in the leaves of plants irrigated using saline water may be attributed to the reduction in the total chlorophylls content as a result of the salinity treatments (as previously mentioned). This reduction in the chlorophyll content leads to a reduction in the rate of photosynthesis which occurs within the leaf tissues, leading in turn to a reduction in the synthesis and accumulation of carbohydrates.

The results in Table (3a) also show that most of the tested humic acid concentrations increased the mean total carbohydrates $\%$ in the leaves of Chorisia speciosa plants, compared to the control. Among the plants receiving the different humic acid treatments, plants sprayed with 1500 ppm humic acid had the highest carbohydrates \% in leaves of 17.73 and $18.05 \%$ in the first and second seasons, respectively. Increases in the carbohydrates \% in the leaves of plants receiving humic acid treatments were also reported by Hussein (2009) on Cryptostegia grandiflora.

Concerning the interaction between the effects of saline irrigation water and humic acid treatments on the carbohydrate content \% of leaves. In the first season, the highest total carbohydrate content of $18.55 \%$ was formed by plants irrigated with tap water and sprayed with humic acid at $1500 \mathrm{ppm}$, In the second season, the highest carbohydrates content of $18.93 \%$ was formed by plants irrigated with tap water and sprayed with humic acid at $1000 \mathrm{ppm}$. On the other hand, the lowest carbohydrate contents 14.00 and $14.74 \%$ in the first and second seasons, respectively) were obtained on plants irrigated using the highest salt concentration at $9000 \mathrm{ppm}$ combined with humic acid at $0 \mathrm{ppm}$ treatment.

\subsubsection{Proline content $(\mathrm{mg} / \mathrm{g})$}

Results of leaf samples taken from plants receiving different irrigation water salinity treatments in Table (3a) show that with increasing the level of salinity in water, the proline contents $(\mathrm{mg} / \mathrm{g})$ in dry leaves was 
generally increased. Accordingly, plants irrigated with the highest salt concentration at $9000 \mathrm{ppm}$ had the highest mean of proline values of 2.25 and $2.25 \mathrm{mg} / \mathrm{g}$ in the first and second seasons, respectively. On the other hand, the plants irrigated with tap water had the lowest mean proline values of 1.10 and $1.14 \mathrm{mg} / \mathrm{g}$ in the first and second seasons, respectively. Similar results were reported by Kumar et al. (2003) on Morus alba, and Woodward and Bennett (2005) on Eucalyptus camaldulensis. The considerable enhancement of proline accumulation in plants irrigated using high salt concentrations may lead to the conclusion that proline plays a role in plant tolerance to salinity. This role was explained by Greenway and Munns (1980), who mentioned that proline can be considered as a stabilizer of osmotic pressure within the cell. Also, Maraim (1990) and Marcum and Murdoch (1994) concluded that proline can make a substantial contribution to cytoplasmic osmotic adjustment.

As for the effect of different combinations of saline irrigation water and humic acid concentrations, it is clear from data in Table (3a) that considerable differences in the proline $(\mathrm{mg} / \mathrm{g})$ were detected in the leaves of plants receiving the different combinations of water salinity and humic acid treatments. The highest mean values of 2.32 and $2.31 \mathrm{mg} / \mathrm{g}$ dry matter in the first and second seasons, respectively, were obtained in plants irrigated with saline water at 9000 ppm, and receiving no humic acid treatment. On the other hand, the lowest proline values of 0.99 and $1.05 \mathrm{mg} / \mathrm{g}$ dry matter in the first and second seasons, respectively, were obtained from plants irrigated with tap water and sprayed with humic acid at $1500 \mathrm{ppm}$. Similar results were reported by Campos et al. (2012) on Jatropha curcas.

Table (3a): Means of chemical constituents characteristics of Chorisia speciosa plants as influenced by salinity (S), humic acid (HA) and their combinations $(\mathrm{S} \times \mathrm{HA})$ in the two seasons of 2012 and 2013.

\begin{tabular}{|c|c|c|c|c|c|c|c|}
\hline \multicolumn{2}{|c|}{ Treatments } & \multicolumn{2}{|c|}{$\begin{array}{c}\text { Chlorophyll content } \\
\text { (SPAD unites ) }\end{array}$} & \multicolumn{2}{|c|}{$\begin{array}{c}\text { Carbohydrates } \\
\text { content }(\%)\end{array}$} & \multicolumn{2}{|c|}{$\begin{array}{c}\text { Proline content } \\
(\mathrm{mg} / \mathrm{g})\end{array}$} \\
\hline Salinity (ppm) & Humic acid (ppm) & 2012 & 2013 & 2012 & 2013 & 2012 & 2013 \\
\hline \multirow{4}{*}{0} & 0 & 42.55 & 47.99 & 16.17 & 17.21 & 1.18 & 1.22 \\
\hline & 500 & 43.94 & 49.36 & 17.34 & 17.74 & 1.13 & 1.17 \\
\hline & 1000 & 45.99 & 51.08 & 18.00 & 18.93 & 1.09 & 1.14 \\
\hline & 1500 & 45.62 & 51.75 & 18.55 & 18.25 & 0.99 & 1.05 \\
\hline \multicolumn{2}{|l|}{ Mean } & 44.52 & 50.04 & 17.51 & 18.03 & 1.10 & 1.14 \\
\hline \multirow{4}{*}{3000} & 0 & 38.37 & 44.13 & 15.11 & 15.74 & 1.72 & 1.73 \\
\hline & 500 & 40.47 & 45.57 & 15.92 & 16.28 & 1.59 & 1.64 \\
\hline & 1000 & 45.88 & 49.66 & 17.60 & 18.42 & 1.55 & 1.59 \\
\hline & 1500 & 46.93 & 50.87 & 18.02 & 18.75 & 1.52 & 1.55 \\
\hline \multicolumn{2}{|l|}{ Mean } & 42.91 & 47.55 & 16.66 & 17.30 & 1.59 & 1.63 \\
\hline \multirow{4}{*}{6000} & 0 & 37.31 & 43.08 & 14.71 & 15.33 & 2.08 & 2.13 \\
\hline & 500 & 40.03 & 45.12 & 15.47 & 16.12 & 2.01 & 2.07 \\
\hline & 1000 & 44.37 & 48.77 & 16.63 & 16.72 & 1.97 & 2.02 \\
\hline & 1500 & 44.56 & 49.46 & 17.08 & 17.76 & 1.93 & 1.98 \\
\hline \multicolumn{2}{|l|}{ Mean } & 41.56 & 46.60 & 15.97 & 16.48 & 2.00 & 2.05 \\
\hline \multirow{4}{*}{9000} & 0 & 35.44 & 41.54 & 14.00 & 14.74 & 2.32 & 2.31 \\
\hline & 500 & 39.72 & 45.14 & 15.36 & 16.11 & 2.24 & 2.24 \\
\hline & 1000 & 42.21 & 47.31 & 16.08 & 16.94 & 2.24 & 2.21 \\
\hline & 1500 & 42.56 & 47.67 & 17.28 & 17.45 & 2.22 & 2.20 \\
\hline \multicolumn{2}{|l|}{ Mean } & 39.98 & 45.41 & 15.68 & 16.31 & 2.25 & 2.24 \\
\hline \multirow{4}{*}{ Mean (HA) } & 0 & 38.42 & 44.18 & 15.00 & 15.75 & 1.82 & 1.85 \\
\hline & 500 & 41.04 & 46.30 & 16.02 & 16.56 & 1.74 & 1.78 \\
\hline & 1000 & 44.61 & 49.20 & 17.08 & 17.75 & 1.71 & 1.74 \\
\hline & 1500 & 44.91 & 49.93 & 17.73 & 18.05 & 1.67 & 1.69 \\
\hline \multirow{3}{*}{ L.S.D.at 0.05} & $\mathbf{S}$ & 1.12 & 1.01 & 0.54 & 0.52 & 0.03 & $\mathbf{0 . 0 3}$ \\
\hline & HA & 0.70 & 0.71 & 0.47 & 0.25 & 0.01 & 0.01 \\
\hline & $\mathbf{H A} \times \mathbf{S}$ & 1.64 & 1.59 & 0.97 & 0.68 & 0.03 & $\mathbf{0 . 0 3}$ \\
\hline
\end{tabular}




\subsubsection{Relative Water Content of leaves (\%)}

Results of leaf samples taken from plants receiving different irrigation water salinity treatments in Table (3b) show that, with increasing the level of salinity in water, the relative water content $\%$ in fresh leaves was generally decreased. Accordingly, the plants irrigated with the highest salt concentration at $9000 \mathrm{ppm}$ had the lowest mean relative water content values of 56.35 and $55.14 \%$ in the first and second seasons, respectively. On the other hand, plants irrigated with tap water had the highest mean relative water content values of 81.95 and $75.12 \%$ in the first and second seasons, respectively. The considerable enhancement of relative water content accumulation in plants irrigated using high salt concentrations may lead to the conclusion that relative water content plays a role in plant tolerance to salinity. This role was explained by Greenway and Munns (1980), who mentioned that relative water content can be considered as a stabilizer of osmotic pressure within the cell.

As for the effect of different combinations of saline irrigation water and humic acid concentrations, it is clear from data in Table (3b) that considerable differences in the relative water content (\%) were detected in the leaves of plants receiving the different combinations of water salinity and humic acid treatments. The highest mean values of 84.40 and $76.47 \%$ in the first and second seasons, respectively, were obtained in plants irrigated with tap water, and receiving humic acid at $1500 \mathrm{ppm}$. On the other hand, the lowest relative water contents 54.85 and $52.59 \%$ in the first and second seasons, respectively, were obtained from plants irrigated with saline water at $9000 \mathrm{ppm}$ and sprayed without humic acid. Similar results were reported by Sapeta et al. (2013) on Jatropha curcas.

\subsubsection{Sodium percentage in leaves $(\%)$}

The results presented in Table (3b) show that $\mathrm{Na} \%$ in the dried leaves of Chorisia speciosa plants was increased steadily with raising the salt concentration in the irrigation water. Accordingly, the least $\mathrm{Na}$ contents of 0.35 and $0.35 \%$ in the first and second seasons, respectively, were found in the leaves of the control plants, whereas the highest contents of 1.85 and $1.90 \%$ in the first and second seasons, respectively, were found in plants irrigated with water containing the highest salt concentration at
9000 ppm. Increases in the $\mathrm{Na}$ contents with increasing the salinity level have been reported by Franklin et al. (2002) on Pinus banksiana, ElFeky (2004) on Erytherina indica and Tecoma stans, and Cassanitia et al. (2009) on ornamental shrubs.

The results in Table (3b) also show that the mean $\mathrm{Na} \%$ content of the leaves was slightly reduced by spraying the plants with $1500 \mathrm{ppm}$ humic acid which gave a sodium contents of 1.08 and $1.10 \%$ in the first and second seasons, respectively, compared to the control. The highest values (1.36 and $1.39 \%$ in the first and second seasons, respectively) were recorded in plants sprayed with humic acid at $0 \mathrm{ppm}$ (control).

Regarding the interaction between the effects of saline irrigation water and humic acid concentrations on the $\mathrm{Na} \%$ of leaves, the data presented in Table (3b) show that the highest values of 2.06 and $2.07 \%$ in the first and second seasons, respectively, were obtained from plants irrigated with saline water at 9000 ppm and sprayed without humic acid. On the other hand, the lowest values of 0.25 and $0.23 \%$ in the first and second seasons, respectively, were obtained from plants irrigated with tap water and sprayed with humic acid at $1500 \mathrm{ppm}$. Increases in the Na contents with increasing the salinity level have been reported by Franklin et al. (2002) on Pinus banksiana, El-Feky (2004) on Erytherina indica and Tecoma stans, and Cassanitia et al. (2009) on a number of ornamental shrubs.

\subsubsection{Chloride percentage in leaves $(\%)$}

From the data presented in Table (3b), it can be seen that chloride \% in the dried leaves of Chorisia speciosa plants was increased steadily with raising the salt concentration in the irrigation water. Accordingly, the lowest $\mathrm{Cl}^{-}$ values $(0.10$ and $0.10 \%$ in the first and second seasons, respectively) were found in control plants, whereas the highest values $(0.62$ and 0.64 $\%$ in the first and second seasons, respectively) were found in plants irrigated with water containing the highest salt concentration at 9000 ppm. Similar increases in the leaf $\mathrm{Cl}^{-}$contents with increasing the salinity level were reported by Helmy (2004) on Senna occidentalis, and Cassanitia et al. (2009) on ornamental shrubs.

The results in Table (3b) also show that the mean leaf $\mathrm{Cl}^{-} \%$ was reduced steadily with raising humic acid concentration. Accordingly, the highest $\mathrm{Cl}^{-}$values $(0.45$ and $0.46 \%$ in the 
Table (3b): Means of chemical constituents characteristics of Chorisia speciosa plants as influenced by salinity (S), humic acid (HA) and their combinations $(\mathrm{S} \times \mathrm{HA})$ in the two seasons of 2012 and 2013.

\begin{tabular}{|c|c|c|c|c|c|c|c|}
\hline \multicolumn{2}{|c|}{ Treatments } & \multicolumn{2}{|c|}{$\begin{array}{l}\text { Chlorophyll content } \\
\text { (SPAD unites ) }\end{array}$} & \multicolumn{2}{|c|}{$\begin{array}{c}\text { Carbohydrate } \\
\text { content }(\%)\end{array}$} & \multicolumn{2}{|c|}{$\begin{array}{c}\begin{array}{c}\text { Proline content } \\
(\mathrm{mg} / \mathrm{g})\end{array} \\
\end{array}$} \\
\hline Salinity (ppm) & Humic acid (ppm) & 2012 & 2013 & 2012 & 2013 & 2012 & 2013 \\
\hline \multirow{4}{*}{0} & 0 & 76.60 & 73.76 & 0.47 & 0.48 & 0.15 & 0.15 \\
\hline & 500 & 83.13 & 74.80 & 0.37 & 0.39 & 0.11 & 0.12 \\
\hline & 1000 & 83.68 & 75.44 & 0.31 & 0.31 & 0.09 & 0.09 \\
\hline & 1500 & 84.40 & 76.47 & 0.25 & 0.23 & 0.07 & 0.06 \\
\hline \multicolumn{2}{|l|}{ Mean } & 81.95 & 75.12 & 0.35 & 0.35 & 0.10 & 0.10 \\
\hline \multirow{4}{*}{3000} & 0 & 72.75 & 69.38 & 1.18 & 1.23 & 0.39 & 0.41 \\
\hline & 500 & 73.79 & 70.75 & 1.15 & 1.166 & 0.38 & 0.38 \\
\hline & 1000 & 75.22 & 71.45 & 1.08 & 1.10 & 0.36 & 0.36 \\
\hline & 1500 & 75.76 & 72.16 & 0.98 & 1.02 & 0.32 & 0.34 \\
\hline \multicolumn{2}{|l|}{ Mean } & 74.38 & 70.93 & 1.09 & 1.13 & 0.36 & $\mathbf{0 . 3 7}$ \\
\hline \multirow{4}{*}{6000} & 0 & 63.21 & 61.07 & 1.74 & 1.80 & 0.58 & 0.60 \\
\hline & 500 & 64.79 & 62.16 & 1.63 & 1.66 & 0.53 & 0.56 \\
\hline & 1000 & 65.18 & 63.18 & 1.42 & 1.54 & 0.47 & 0.49 \\
\hline & 1500 & 65.82 & 64.37 & 1.43 & 1.43 & 0.42 & 0.45 \\
\hline \multicolumn{2}{|l|}{ Mean } & 64.75 & 62.69 & 1.55 & 1.61 & 0.50 & 0.52 \\
\hline \multirow{4}{*}{9000} & 0 & 54.85 & 52.59 & 2.06 & 2.07 & 0.70 & 0.70 \\
\hline & 500 & 56.65 & 55.19 & 1.88 & 1.94 & 0.64 & 0.65 \\
\hline & 1000 & 56.74 & 56.00 & 1.78 & 1.85 & 0.60 & 0.62 \\
\hline & 1500 & 57.19 & 56.78 & 1.67 & 1.74 & 0.56 & 0.58 \\
\hline \multicolumn{2}{|l|}{ Mean } & 56.35 & 55.14 & 1.85 & 1.90 & 0.62 & 0.64 \\
\hline \multirow{4}{*}{ Mean (HA) } & 0 & 66.85 & 64.20 & 1.36 & 1.39 & 0.45 & 0.46 \\
\hline & 500 & 69.59 & 65.72 & 1.26 & 1.29 & 0.41 & 0.43 \\
\hline & 1000 & 70.20 & 66.52 & 1.15 & 1.20 & 0.38 & 0.39 \\
\hline & 1500 & 70.79 & 67.44 & 1.08 & 1.10 & 0.34 & 0.36 \\
\hline \multirow{3}{*}{ L.S.D.at 0.05} & $\mathbf{S}$ & 2.53 & 1.00 & 0.055 & 0.032 & 0.020 & 0.015 \\
\hline & HA & 0.43 & 0.52 & 0.038 & 0.019 & 0.013 & 0.007 \\
\hline & $\mathbf{H A} \times \mathbf{S}$ & 2.63 & 1.34 & 0.080 & 0.039 & 0.020 & 0.015 \\
\hline
\end{tabular}

first and second seasons, respectively) were recorded in the leaves of the control plants, whereas the plants sprayed with the highest humic acid concentration $1500 \mathrm{ppm}$ had the lowest $\mathrm{Cl}^{-}$values $(0.34$ and $0.36 \%$ in the first and second seasons, respectively).

Regarding the interaction between effect of saline irrigation water and humic acid concentrations on the $\mathrm{Cl} \%$, the data in Table (3b) show that the highest mean values of 0.70 and $0.70 \%$ in the first and second seasons, respectively, were obtained in plants irrigated with saline water at $9000 \mathrm{ppm}$ and sprayed with tap water, while the least mean values 0.07 and $0.06 \%$ in the first and second seasons, respectively, were recorded in plants irrigated with tap water and sprayed with humic acid at $1500 \mathrm{ppm}$. Similar increases in the $\mathrm{Cl}^{-}$contents with increasing the salinity level were reported by Helmy (2004) on Senna occidentalis, Cassanitia et al. (2009) on a number of ornamental shrubs.

\section{Conclusions}

The results reported about the vegetative growth parameters and chemical compositions of Chorisia speciosa showed that the best spraying treatments of humic acid were 1000 and 1500 ppm and irrigation with tap water (control). It can also been seen from the data that spraying the plants with humic acid reduced the undesirable effect of salinity Thus, it can be concluded that the plants irrigated with water of lower quality (water drainage) with salinity at level of concentration $6000 \mathrm{ppm}$, the damage caused by the increasing salinity can be reduced by spraying the plants once amonth with humic acid at a rate of $1500 \mathrm{ppm}$. In some cases, the humic acid treatments helped to overcome the adverse effect of the salinity.

Generally, the results obtained to irrigate Chorisia speciosa plants 3 times per week with the use of the water level of salinity of irrigation 
of no more than $6000 \mathrm{ppm}$ along with acid humic at a rate of $1000 \mathrm{ppm}$ gave improvements good vegetative growth and some chemical components of plants Chorisia speciosa planted in sandy soil.

\section{REFERENCES}

Abd El-Aziz N. G., Mazher A. A. M. and Habba E. (2006). Effect of foliar spraying with ascorbic acid on growth and chemical constituents of Khaya senegalensis grown under salt condition. American- Eurasian J. Agri. \& Environ. Sci., 1(3): 207 - 214.

Ashish D. P., Nilesh S. P., Indu B. P. and Amar N. P. (2010). Growth, water status and nutrient accumulation of seedlings of Jatropha curcas L. (Euphorbiaceae) in response to soil salinity. Anales de Biologia, 32: 59-71.

Aslam Z., Awan A. R., Qureshi M. A. A., Mahmood T., Haq M. I., Chaudhry A. K. and Malik K. A. (2002). Growth, ion uptake, agro-industrial uses and environmental implications of Eucalyptus camaldulensis in saline systems. In : Prospects for Saline Agriculture. Kluwer Academic Publishers, Pakistan, 37: 277 285.

Awan M. F., Siddiqui T. I., Khan R. A. and Shah A. H. (2002a). Combined effect of salinity and industrial effluents on the growth of Eucalyptus camaldulensis Dehnh. Pak. J. Agric. Sci., 39(2): 80-82.

Awan M. F., Siddiqui T. I., Khan R. A. and Shah A. H. (2002b). Interaction of salinity and industrial effluents on the growth of Dalbergia sissoo (Shisham) seedlings. Int. J. Agric. Biology, 4(2): 240-241.

Barrs D. (1968). Determination of water deficits in plant tissues. In: water deficits Vol.1 pp. 235 - 368. and plant growth. T.T. Kozlowski (ed.). Academic Press, London, uk.

Bates L.S., Waldern R.P. and Teare L. D. (1973). Rapid determination of free proline under water stress studies. Plant and Soil, 39: 205-207.

Campos M., Hsie B.S., Granja J.A., Correia R.M., Cortez J.S., and Pompelli M.F. (2012). Photosynthesis and antioxidant activity in Jatropha curcas L. under salt stress. Brazilian Soc. Plant Physiol., 24(1): 55-67.
Cassanitia C., Leonardia C. and Flowers T. J. (2009). The effect of sodium chloride on ornamental shrubs. Sci. Hort., 122(4): 586593.

Cavalcante H. L., Da Silva R. S., Albano F. G., De Lima F. N. and Marques A. Des. (2011). Foliar spray of humic substances on seedling production of papaya (Pawpaw). J. Agron., 10(4): 118-122.

Chen Y. and Aviad T. (1990). Effects of humic substances on plant growth. In: McCarthy P, Calpp CE, Malcolm RL. Bloom, Readings. ASA and SSSA (pub), Madison, WI., USA pp: 161-186.

Chen Y., Clapp C.E. and Magen H. (2004). Mechanisms of plant growth stimulation by humic substances: The role of organic-iron complexes. Soil Sci. and Plant Nut., 50: 1089-1095.

Dias L.A.S., Kageyama P.Y. and Issiki K. (1992). Qualidade de luze germinacão de sementes de espécies arbóreas e tropicais. Acta Amazonica, 1:79-84.

Dubios M., Gilles K., Hamlton, J., Rebers P., and Smith F.(1956). Colourimetric method for determination of sugars and related substances. Analytical Chemistry, 28(3): 350- 356.

El-Bagoury H., Hossni Y. A., El-Tantawy A., Shehata M. and Asmael R. (1999). Effect of saline water in irrigation on growth and chemical composition of Casuarina equisetifolia L. seedling. Egypt. J. Hort., 26: 47-57.

El-Feky A. E. A. M. (2004). Respone of Erythrina indica and Tecoma stans plants to some treatments. Ph.D. Thesis, Fac. Agric., Cairo Univ., Egypt, 186p.

EI-Juhany L. and Aref L. M. (2005). Interactive effects of low water supply and high salt concentration on the growth and dry matter partitioning of Conocarpus erectus seedlings. Saudi J. Biol. Sci., 12(2): 147157.

El-Juhany L., Aref L. M. and Ahmed A. T. M. (2008). Response of Eucalyptus camaldulensis, Eucalyptus intertexta and Eucalyptus microtheca seedlings to irrigation with saline water. World of Agriculture Sciences, 4(5): 825 - 834.

El-Khateeb M. A., Nasr A. A., Fahmy A. N. and Dorgham A. H. (2010). Effect of $\mathrm{GA}_{3}$ and growth biostimulants on growth and chemical composition of Calia 
secundiflora plants. J. Hort. Sci. \& Ornamen. Plants., 2(2): 118-124.

Fathy M. A., Gabr M. A. and El-Shall S. A. (2010). Effect of humic acid treatments on "Canino" apricot growth, yield and fruit quality. New York Sci. J., 3(12): 109-115.

Ferrara G., Pacifico A., Simeone P. and Ferrara E. (2008). Preliminary study on the effects of foliar application of humic acid on "Italia" table grape. J. Int. des Sciences de la Vigne et du Vin, 42(2): 79-87.

Franklin J. A., Zwiazek J. J., Renault S. and Croser C. (2002). Growth and elemental composition of jack pine (Pinus banksiana) seedlings treated with sodium chloride and sodium sulfate. Trees Struct. and Funct., 16(4/5): $325-330$.

Genhua N., Denise R., Mike M., John J. and Girisha G. (2012). Responses of Jatropha curcas to salt and drought stresses. Int. J. Agron. (2012), Article ID 632026:1-7.

Greenway H. and Munns R. (1980). Mechanisms of salt tolerance in non-halophytes. Ann. Rev. of Plant Physiol, 31: 149-190.

Gupta N. P., Meena S. K., Gupta S. and Khandelwal (2002). Gas exchange, membrane permeability, and ion uptake in two species of Indian jujube differing in salt tolerance. Photosynthetica, 40(4): 535 539.

Helmy S. S. (2004). Effect of irrigation intervals and salt concentrations on the growth and chemical composition of Senna occidentalis L. Link. M.Sc. Thesis, Fac. Agric., Cairo Univ., Egypt, 135 p.

Hussein M. M. (2009). Effect of gibberellic acid and chemical fertilization on growth and chemical composition of Cryptostegia grandiflora. J. hort. Sci. \& Ornamental Plants, 1(2):27-38.

Jackson N. L. (1958). Soil Chemical Analysis. Constable. Ltd. Co., London,UK., 498 p.

Khaled H. and Fawy H.A. (2011). Effect of different levels of humic acids on the nutrient content, plant growth, and soil properties under conditions of salinity. Soil \& Water Res., 6(1): 21-29.

Kumar S., Reddy A. A. and Sudhakar C. (2003). $\mathrm{NaCl}$ effects on proline metabolism in two high yielding genotyps of mulberry (Morus alba L.) with contrasting salt tolerance. Plant Sci., 165(6): 1245-1251.

Maraim K. B. (1990). Physiological parameters of salinity tolerance in $\mathrm{C}_{4}$ turfgrasses.
Dissertation Abstracts International. B: Sciences and Engineering, 51 (5): 484 B. (C.f. Hort. Abst., 61: 10274).

Marcum K. B. and Murdoch C. L. (1994). Salinity tolerance mechanisms of six $\mathrm{C}_{4}$ turfgrasses. J. Amer. Soc. Hort. Sci., 119 (4): 779-784.

Pio Correa M., (1978). Dicionário das plantas úteis do Brasil e das exóticas cultivadas. Ministério da Agricultura, Rio de Janeiro, brazil.

Piper C.S. (1947). Soil and Plant Analysis. The Univ. of Adelaide, pp. 258-274.

Ritche J.J. (1974). Atmospheric and soil water influences on the plant water balance. Agric. Meth., 14, 1993 - 1998.

Santos E. (1967). Bombacáceas. In: Flora Ilustrada Catarinense (R. Reitz, ed.). Herbário Barbosa Rodrigues. Itajaí.

Sapeta H., Miguel C., Tiago L., Joao M., Piet L., Margarida O. (2013). Drought stress response in Jatropha curcas: Growth and physiology. Environ. Exper. Bot., 85: 7684.

Sayed A. B. F. (2006). Physiological studies on Ficus alii plants. M.Sc. Thesis, Fac. Agric., Cairo Univ., Egypt.

Sharif F. and Khan A. U. (2009). Alleviation of salinity tolerance by fertilization in four thorn forest species for the reclamation of salt-affected sites. Pak. J. Bot., 41(6): 29012915.

Snedecor G. and Cochran W. (1974). Statistical Methods. Sixth Ed. Iowa State University Press. Ames,. Iowa. USA.

St. Arnaud M. and Vincent G. (1990). Influence of high salt levels on the germination and growth of five potentially utilizable plants for median turfmg in northern climates. J. Environ. Hort., 6(4): 118-121. (C.f. Hort. Abst., 61, 10052).

Tejada M. and Gonzalez J. L. (2003). Influence of foliar fertilization with amino acids and humic acids on productivity and quality of asparagus. Biol. Agric. Hort., 21:277-291.

Vaughan D., Malcom R.E. and Ord B.G. (1985). Influence of humic substances on biochemical processes in plants. In: Vaughan, D., Malcom, R.E. (Eds.), Soil Organic Matter and Biological Activity. Martinus Nijhoff/Junk W, Dordrecht, The Netherlands, pp: 77-108.

Woodward A. J. and Bennett I. J. (2005). The effect of salt stress and abscisic acid on 
proline production, chlorophyll content and growth of in vitro propagated shoots of Eucalyptus camaldulensis. P. C. T. O. C., 82: 189-200.

Yadava U. (1986). A rapid and non destructive method to determine chlorophyll in intact leaves. Hort. Sci., 21(6): 1449-1450.

Yasseen B. T., Mohammed H. A. and Soliman E. D. (1987). Growth of prophyll, and proline accumulation due to salt stress in three barley cultivars. Iraqi J. Agric. Sci., 5(2): 155-166. (C. f. Field Crop Abst., 40: 5633).

Zaghloul S. M., El-Quesni F. E. M. and Mazhar A.A.M. (2009). Infiuence of potassium humate on growth and chemical constituents of Thuja orientalis L seedling. Ozean J. Appl. Sci., 2(1): 73-78.

$$
\begin{aligned}
& \text { تأثير معاملات الملوحة وحمض الهيوميك على النمو والتركيب الكيميائى لنباتات الكوريزيا } \\
& \text { نادر أحمد الثنهورى - نشوى حسن محمد" ـ محمد زيدان سالم*** } \\
& \text { فرع بحوث الحدائق النباتية بأنطونيادس - *فرع بحوث الأشجار الخشبية بأنطونيادس - معهد بحوث البساتين - مركز }
\end{aligned}
$$

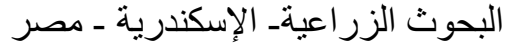

$$
\begin{aligned}
& \text { **** قسم الأشجار الخشبية وتكنولوجيا الأخشاب - كلبة الزر اعة الإكة (الثاطبى) - جامعة الإسكندريةــ مصر }
\end{aligned}
$$

\section{ملخص}

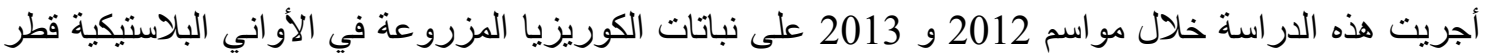

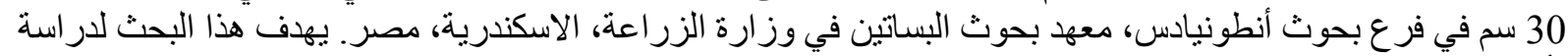

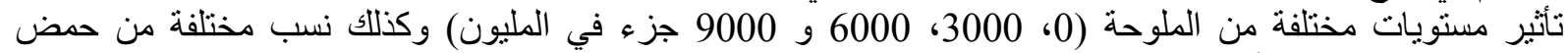

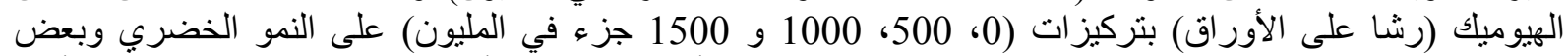

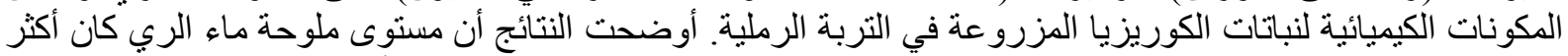

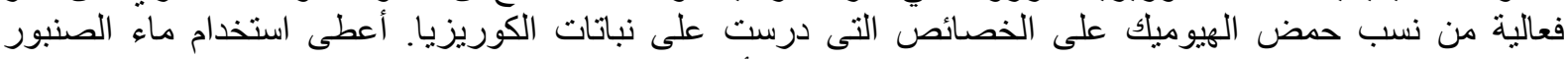

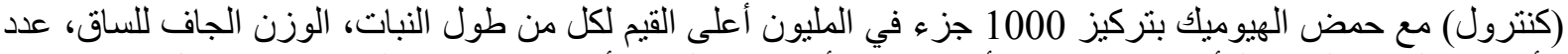

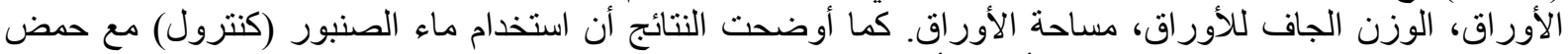

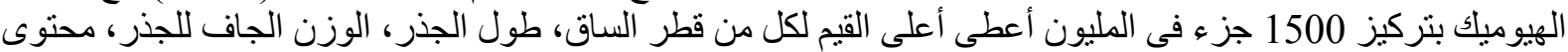

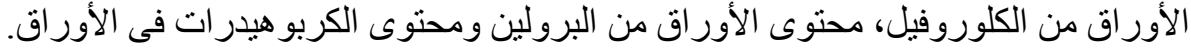

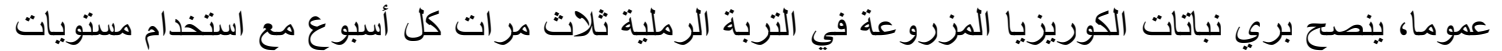

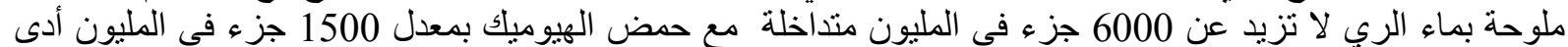

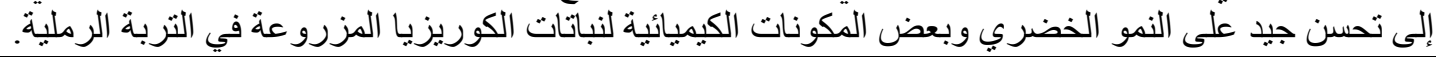

